\title{
Unconsummated Marriage
}

\author{
Atena Naseri ${ }^{1}$, Ali Akbar Malekirad ${ }^{2}$, Azade Gorjinia ${ }^{2}$, Hassan Ashayeri ${ }^{3}$, Ayatolah Fathi', \\ Arezoo Fathi ${ }^{*}$ \\ ${ }^{1}$ Psychology Department, Science and Research Branch, Islamic Azad University, Alborz, Iran \\ ${ }^{2}$ Biology Department, Payame Noor University, Tehran, Iran \\ ${ }^{3}$ Faculty of Rehabilitation Science, Iran University of Medical Science, Tehran, Iran \\ ${ }^{4}$ Department of Psychology, University of Tabriz, Tabriz, Iran \\ ${ }^{5}$ Clinical Psychology Department, Science and Research Branch, Islamic Azad University, Arak, Iran \\ Email: ${ }^{*}$ ar1988 fathi@yahoo.com
}

Received 26 December 2014; accepted 8 February 2015; published 15 February 2015

Copyright (C) 2015 by authors and Scientific Research Publishing Inc.

This work is licensed under the Creative Commons Attribution International License (CC BY). http://creativecommons.org/licenses/by/4.0/

(c) (1) Open Access

\begin{abstract}
The main purpose of this research is to help couples that have problems in early ejection in man and veganism's problem in woman that after 2 months has been cured by using scientific and non-drug method, successfully. This case is related to couples who live in Arak and both of them are 21 years old and their education level is Diploma. They refer to clinic center and are asking help from consulters after one year of their unconsummated marriage. Man is involved with problem of early injection and woman is involved with veganism's problem. Treatment has been done by teaching relaxation to woman for 2 weeks and little by little along with day dreaming that is related to sexual. In the next stage, the researchers ask her in relaxing time to enter fingers in vagina. Manner therapy has been used for man that usually consists of start-stop and squeeze techniques. At last, after successful performance, first sexual relationship happens. It is noticeable that unconsummated marriage is treatable with a simple and safe method and low cost in a short time. Regarding this matter that veganism's and early ejection are as sexual disorders and are most prevalent kind of sexual disorders, so present research concludes that unconsummated marriage is treatable by psychology and non-drug treatment which prevents marriage from failing.
\end{abstract}

\section{Keywords}

Unconsummated Marriage, Premature Ejaculation, Vaginismus, Anxiety in Sexual Performance

\section{Introduction}

Unconsummated marriage refers to marriage that wife and husband never have sexual relationship [1]. For the

*Corresponding author. 
first time, Balint (1961) pointed to unconsummated marriage disorder in his article that called another part of medicine and up to now lots of cases reported in the entire world [2]. Many cases in Iran show that most important mental factors (UCM) in women are because of fear of sexual relationship, unhappy or undesired view to their husband and anxiety in sexual performance and premature ejaculation in men [3]. This disorder causes infertility and in many cases divorces in couples when there wouldn't be any cure [4]. Bardan, et al. (2006) in a study on unconsummated marriage in Egypt investigated etiologic factors that functional disorder was the most prevalent etiologic factors which reported in $74.4 \%$ cases and among them the main mental factors was interference in functional concerns in $52.9 \%$ and also, $21.5 / \%$ of remaining cases were related to other mental factors. But among other etiologic UCM reasons, organic factors interfere was in $6 / .8 \%$ cases, vaginismus in $8 / 4 \%$, premature ejaculation in $3.1 \%$ and etiology with unknown factors in $6.8 \%$ cases. In this research, anxiety performance reported as a key factor UCM [5] and also in one study in Iran the frequency of UCM has been reported as $1.5 \%$ [6]. Moreover, some Iranian studies have been reported that many factors can be lead to UCM and psychological treatment can improve the disease [7]-[13]. Vaginismus is reduction involuntary muscles contraction in one third of external vagina that prevents sexual relationship. Based on mental patients division (DSM-IV-TR), this disorder formed dyspareunia and sexual pain. When there is no other diseases (infections, surgical damages), it can be identify existing symptoms. Although, some women just have vaginismus in time of sexual relationship, this involuntary contraction may prevent to enter spikulum to vagina in genital system checkup time.

Woman who suffers from this disorder may have willing to sexual relationship consciously but prevent to it unconsciously. Painful sexual defined in this way: permanent pain in time of attempting for entering to vagina or in time of complete entering to vagina or in time of vagina mating and penis. Manager group of international conference updates this definition as: painful sexual is pain in time of entrance, not just in time of attempting to enter. Vaginismus is a kind of prevention or unnatural fear that causes contracted involuntary in pelvis muscles prevention or fear of pain. In this situation, other structural or physical disorders should be regarded. The manager group in international conference added that vaginismus usually prevents to complete entrance of genital organ (or other objects) and entering to vagina is possible but is followed by pain and discomfort. 15 to 17 percent of women who refer to sexual cure clinics for consulting have problems with veganism. It can be used smoothing substances vagina and estrogen for easy entrance to vagina of women who are involved with atrophy vagina. In addition to treatment of some diseases such as vaginismus and endometriosis and atropine, women who are suffering from sexual pain disorder can use mental consulting and training. Guideline that is related to relaxing muscles and using dilator vaginal also can be useful and profitable. In spite that some of clinical doctors know entrance to vagina as a purpose of cure, but we believe that enjoyment of sexual in woman and her husband is better criteria.

Based on five descriptive researches, the rate of prevalence before time, fast or premature ejaculation is between 9 to 31 percent. According to a study premature ejaculation that is called early or fast ejection is based on three scales: 1-short hidden stage of ejection 2-losing control 3-mental anxiety in patients or couples. One of symptoms in diagnosing premature ejaculation is time of hidden stage (time of starting sexual to ejection) which is 2 minutes or fewer. Nowadays, men who have PE permanent problem has been cured by drugs like open select-absorb serotonin or SSRIs inhibitor, none sensing special positional drugs and also 5-Phosphide asters inhibitors (these drugs are sort of sildenafil drug). Men who have environmental or earning PE have been cured based on their desire or their couples' desire through the method of drug therapy or manner therapy. Manner therapy usually consists of (stop-start technique) or (squeeze technique) [13] [14].

\section{Population of Study}

This case is related to couples who live in Arak and both of them have 21 years old that they refer to consulting center and asking for help after one year unconsummated marriage. Both of them have diploma. Man is involved with premature ejaculation and woman is involved with vaginismus. The researchers diagnose vaginismus, UCM and premature ejaculation by using DSM-IV criteria and evaluate early ejection by international index of erectile function (IIEF). After 2 months, they have cured by applying the scientific and non-drug method. The main problem about this couple is related to woman's fear in sexual relationship and creating vaginismus in relationship time. Treatment has been started by teaching relaxation to woman for 2 weeks and little by little along with day dreaming has been done that is related to sexual. In the next stage, the researchers ask her in relaxing 
time to enter fingers in vagina. In order to cure man, manner therapy that usually consists of start-stop techniques and squeeze techniques has been used. At last after successful performance, first sexual relationship happens. It is noticeable that unconsummated marriage is treatable with a simple, safe and low cost method in a short time.

\section{Discussion}

Sexual manner is a reaction to one biology motivation that is important for elevating generation and also it is effective on satisfaction of married life. Sexual problems can have unpleasant effect on peoples' life. Vaginismus is one of prevalent sexual problems that is consist of contraction of involuntary muscles in one-third of external vagina that prevent to entering males' genital organ and sexual relationship [1]. These diseases often see in women with upper educational, economical and social situation. Sometimes the reason of this disease is a sexual trauma like molester. Religious strict also is one of the reasons [1]. Regarding clinical experience of researchers about patient who affected by Vaginismus, anxiety diseases have seen with upper prevalent in people who affected by sexual problems [2]-[4].

Someone who is ready for panic attack after failure of non sexual relationship or woman who is suffering from avoiding sexual relationship after trauma molester can be signs of anxiety in this disease and this anxiety disorders that are related to diseases are curable with different drug methods. This is true while continuing this disorder lead to unconsummated marriage, lack of satisfaction in couples in their married life and disordering in relation between individuals or even divorce [5]. Vaginismus is one of main reason in unconsummated marriage [6]. According to the history of men and women who have previous fear, it can be say that they are in exposure to unconsummated marriage more than others [15] [16]. It has been suggested that different methods of mental cure and consulting can be used for curing this disorder regarding mentioned history about mental reasons of Vaginismus that lead to unconsummated marriage.

\section{Conclusion}

Because discussion about sexual matter is not acceptable culturally in Iran and on the other hand, other sexual disorders often cause the interruption in family and divorce, so the lack of attention to this disorder causes enduring in this problem. In regard to the present research, it can be concluded that unconsummated marriage disorder via psychological and non-drug treatment and correct and on time training before marriage is curable. It can prevent marriage from failing.

\section{References}

[1] Kaplan, H.L. and Sadock, B.J. (1998) Synopsis of Psychiatry. Behavioural Sciences, Clinical Psychiatry. 8th Edition, Williams \& Wilkins, Lippincott, 708-709.

[2] Balint, M. (1961) The Other Part of Medicine. Lancet, 1, 40-42. http://dx.doi.org/10.1016/S0140-6736(61)92203-6

[3] Barati, A.H. and Mehrabi, F. (1999) Inspection Reasons Unconsummated Marriage in Iran. Notebook Article Conference All over Medical Thesis in 1999, 18-19.

[4] Watson, J.P. and Brockman, B. (1982) A Follow-Up of Couples Attending a Psychosexual Problems Clinic. British Journal of Clinical Psychology, 21, 143-144. http://dx.doi.org/10.1111/j.2044-8260.1982.tb00543.x

[5] Badran, W., Moamen, N., Fahmy, I., El-Karaksy, A., Abdel-Nasser, T.M. and Ghanem, H. (2006) Etiological Factors of Unconsummated Marriage. International Journal of Impotence Research, 18, 458-463. http://dx.doi.org/10.1038/sj.ijir.3901452

[6] Amini, M., Ozgoli, G., Azar, M. and Alavi Majd, H. (2008) Study of Unconsummated Marriage and Its Associated Factors In Women Attending Clinics Health and Hospitals Medical University of Shahid Beheshti University in Tehran in 2009. Pajohande, 2, 73-78.

[7] American Paychiatric Association (2000) Diagnotic and Statistical Manual of Mental Disorder Text-Revised. 5th Edition, APA, Washington DC, 925.

[8] Mirzaie, N. and Saremi A. (2002) A Fourteen Year Unconsummated Marriage and Its Successful Treatment (A Case Report). Journal of Reproduction and Infertility, 3, 59-63. (Full Text in Persian)

[9] Semnani, Y. and Razzaghzadeh, B. (2003) Management of Unconsummated Marriage after 14 Years. Journal of Qazvin University of Medical Sciences, 7, 89-93. (Full Text in Persian)

[10] Mehrabi, F. and Dadfer, M. (2003) The Role of Psychological Factors in Sexual Function Disorders. Iranian Journal of 
Psychiatry and Clinical Psychology, 9, 1-14. (Text in Persian)

[11] Bolourian, Z. and Ganjloo, J. (2007) Evaluating Sexual Dysfunction and Some Related Factors in Women Attending Sabzevar Health Care Centers. The Journal of Reproduction and Infertility, 8, 163-170. (Full Text in Persian)

[12] Zargooshi, J. (2008) Male Sexual Dysfunction in Unconsummated Marriage: Long-Term Outcome in 417 Patients. The Journal of Sexual Medicine, 5, 2895-2903 http://dx.doi.org/10.1111/j.1743-6109.2008.01004.x

[13] Ghorbani, B., Arefi, S., Modabberi Saber, Y. and Sadri Ardekani, H. (2006) Successful Infertility Treatment and Spontaneous Pregnancy in an Unconsummated Marriage after 7 Years. The Journal of Reproduction and Infertility, 7, 284289. (Full Text in Persian)

[14] Zargooshi, J. (2000) Unconsummated Marriage: Clarification of Aetiology; Treatment with Intracorporeal Injection. British Journal of Urology International, 86, 75-79. http://dx.doi.org/10.1046/j.1464-410x.2000.00727.x

[15] McMahon, C.G. and Touma, K. (1999) Treatment of Premature Ejaculation with Paroxetine Hydrochloride as Needed: 2 Single Blind Placebo Controlled Crossover Studies. Journal of Urology, 161, 1826-1830. http://dx.doi.org/10.1016/S0022-5347(05)68816-7

[16] Seman, J. (1956) Premature Ejaculation: New Approach. Southern Medical Journal, 49, 353-358. 
Scientific Research Publishing (SCIRP) is one of the largest Open Access journal publishers. It is currently publishing more than 200 open access, online, peer-reviewed journals covering a wide range of academic disciplines. SCIRP serves the worldwide academic communities and contributes to the progress and application of science with its publication.

Other selected journals from SCIRP are listed as below. Submit your manuscript to us via either submit@scirp.org or Online Submission Portal.
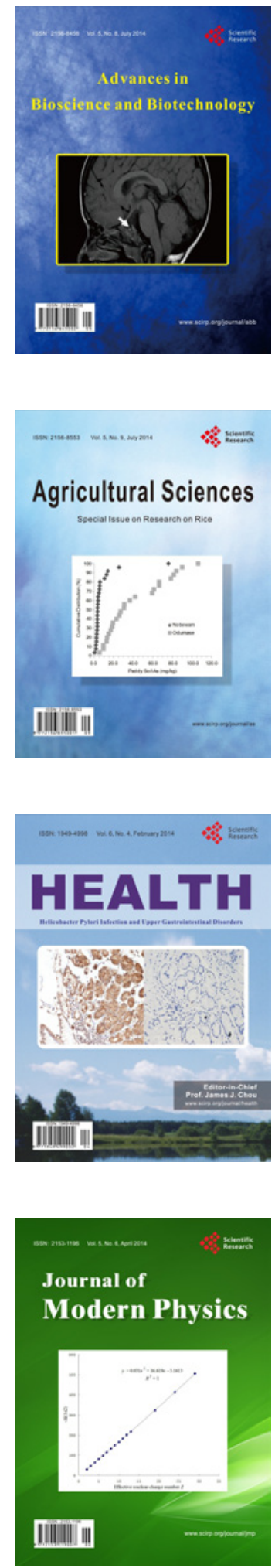


Creative Education
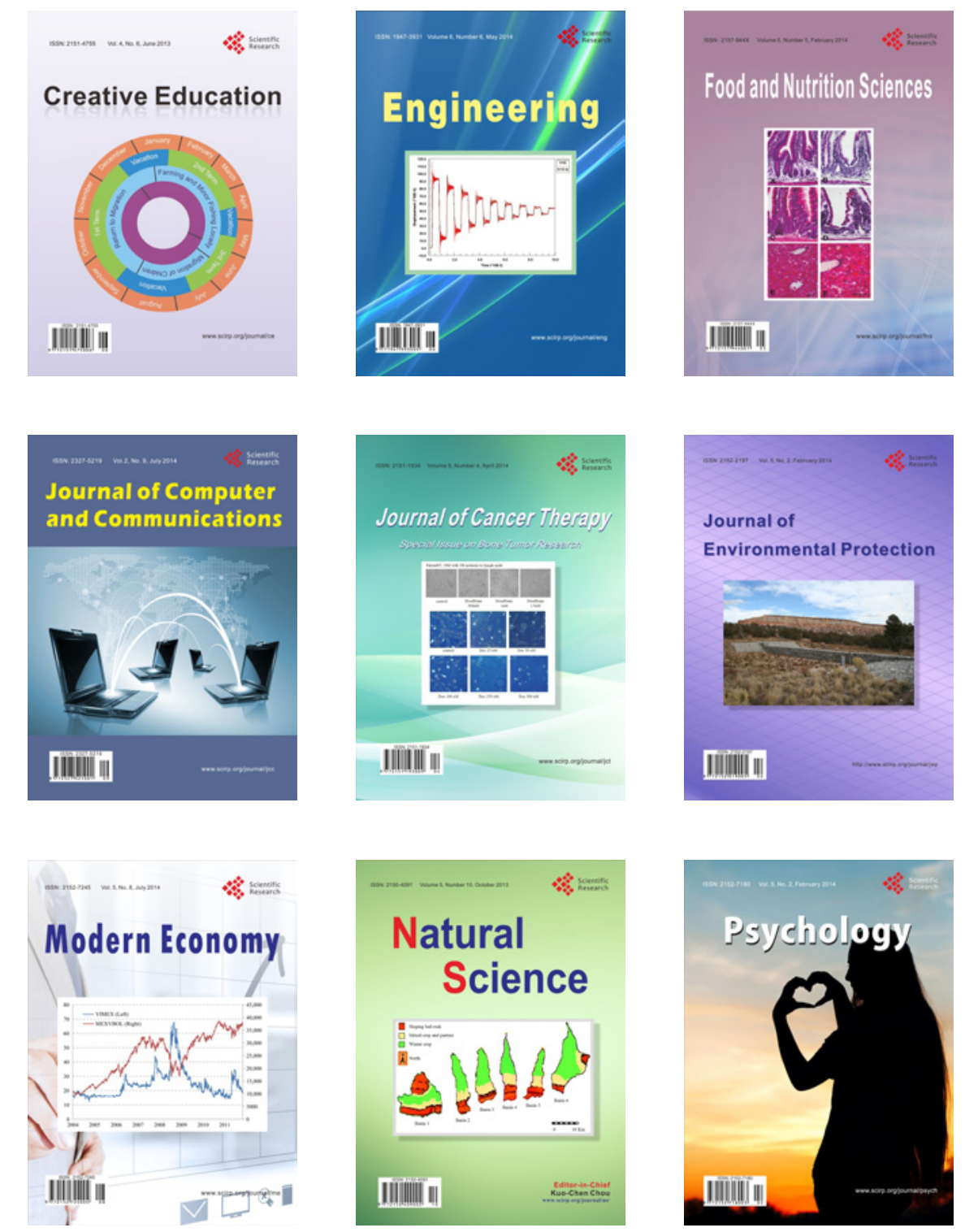